\title{
KARAKTERISTIK BRIKET DARI KOMPOSIT SAMPAH BUAH, SAMPAH PLASTIK HIGH DENSTYY POLYETHYLENE (HDPE) DAN TEMPURUNG KELAPA SEBAGAI BAHAN BAKAR ALTERNATIF DI RUMAH TANGGA
}

\author{
Yenni Ruslinda, Fitratul Husna, Arum Nabila
}

Jurusan Teknik Lingkungan, Fakultas Teknik, Universitas Andalas

Kampus Limau Manis, Unand Padang 25163, Indonesia

Email: yenni@ft.unand.ac.id

\begin{abstract}
This study aims to examine the characteristics of briquettes from fruit waste, HDPE plastic waste, and coconut shell composite, as an alternative fuel. Characteristic tests include physical characteristics (density and compressive strength), chemical characteristics (moisture, volatile content, fixed carbon, ash content, calorific value), and cost calculation for making briquettes. Physical characteristics tests obtained that density is between 0.60 to $0.89 \mathrm{~g} / \mathrm{cm}^{3}$ and compressive strength is between 0.88 to $6.87 \mathrm{~kg} / \mathrm{cm} 2$. Chemical characteristics tests found that water content 5.73 - 9.06\%; volatile content 70.02 - 79.92\%; fixed carbon 12.39 - 18.41\%; ash content of $1.47-4.86 \%$, and calorific value 4549 - 7213 cal/g. Cost for making briquettes range between 0.56 to 0.86 rupiahs $/ \mathrm{kcal}$. Except for compressive strength parameter, other parameters are in the standard range of biobriquettes quality according to Permen ESDM No. 047 Tahun 2006. Optimum briquette found in this research is a mixture of $20 \%$ fruit waste, $20 \%$ of plastic waste HDPE, and 60\% coconut shell. Briquettes made as a mixture of those three raw material with that composition is optimum as an alternative fuel, because it produces higher calorific value and lower cost.
\end{abstract}

Keywords: alternative fuels, briquettes, coconut shell, fruit waste, HDPE plastic waste

\section{PENDAHULUAN}

Bahan bakar fosil, khususnya minyak saat ini masih merupakan bahan bakar yang paling banyak digunakan di Indonesia untuk pemenuhan kebutuhan sehari-hari. Akibatnya cadangan minyak bumi yang tersedia semakin lama akan semakin menipis. Apabila terus dikonsumsi tanpa ditemukannya cadangan minyak baru, diperkirakan cadangan minyak di Indonesia akan habis dalam kurun waktu 10-15 tahun mendatang. Hal ini harus segera diimbangi dengan penyediaan sumber energi alternatif yang renewable, melimpah jumlahnya, dan murah harganya sehingga terjangkau oleh masyarakat luas (Hermawan, 2006).

Abdullah(2002) menyatakan bahwa sampah yang dihasilkan di kota-kota besar di Indonesia bervariasi antara 0,46-3,50 $\mathrm{kg} /$ orang/hari. Semakin tinggi produksi sampah kota yang dihasilkan dan semakin terbatas lahan untuk pembuangan sampah menjadikan sampah sebagai permasalahan yang banyak dihadapi di berbagai kota besar.

Sampah buah-buahan termasuk ke dalam sampah organik yang banyak dihasilkan di perkotaan dan memiliki potensi untuk digunakan sebagai sumber energi. Produksi buah-buahan di Indonesia sangat bervariasi dan tergantung pada musim, salah satu contohnya saja buah durian. Produksi durian lokal di Indonesia adalah sebesar 683.232 ton/tahun (Nuriana, dkk, 2012). Tidak jauh berbeda dengan buahbuahan, produksi buah kelapa di Indonesia rata-rata 15,50 milyar butir/tahun, yang akan menghasilkan 0,75 juta ton tempurung kelapa dan masih sangat minim sekali pemanfaatannya.

Oleh karena itu, perlu dilakukan optimalisasi untuk meningkatkan efektivitas dan efisiensi sampah buah dan tempurung kelapa sebagai salah satu sumber energi terbarukan, sekaligus dapat menjadi alternatif penanggulangan sampah perkotaan yaitu dengan mengolahnya menjadi briket arang. Briket adalah bahan bakar padat yang dapat digunakan sebagai sumber energi alternatif yang mempunyai bentuk tertentu. Briket arang adalah arang yang diolah lebih lanjut menjadi bentuk briket (penampilan dan kemasan yang lebih menarik) yang dapat digunakan untuk keperluan bahan bakar sehari-hari.

Salah satu usaha yang dilakukan untuk menaikkan nilai kalor briket yang berasal dari biomassa agar memenuhi standar briket bio-batubara adalah dengan penambahan campuran yang dapat menaikkan nilai kalor, salah satunya adalah dengan plastik High Density Polyethylene (HDPE). Sebagai contoh, penelitian yang dilakukan oleh Prasetiyo (2008) 
menggunakan bahan baku berupa sampah plastik HDPE sebagai campuran eko-briket lignoselulosa menghasilkan nilai kalor sebesar 8427,27 kal/g, dan telah memenuhi standar nilai kalor bio-batubara. Nilai kalor tersebut juga lebih besar dari eko-briket yang menggunakan campuran plastik low density polyethylene (LDPE), polypropilene (PP), dan polyethylene terephthalate (PETE). Komposisi sampah plastik dalam briket diharapkan tidak terlalu banyak, kurang lebih sebanyak 20\% agar tetap memenuhi standar baku mutu emisi yang telah ditetapkan (Listiyanawati, 2008).

\section{TUJUAN}

Penelitian ini bertujuan melakukan uji karakteristik fisik dan kimia briket dari komposit sampah buah, sampah plastik HDPE dan tempurung kelapa, membandingkan hasil pengujian dengan standar mutu briket bio-batubara yaitu Permen ESDM No. 047 Tahun 2006, menghitung biaya pembuatan briket serta membandingkan hasil pengujian masingmasing variasi briket sehingga didapatkan briket optimum.

\section{METODOLOGI PENELITIAN}

\section{Persiapan alat dan bahan}

Peralatan yang digunakan dalam penelitian ini antara lain drum karbonisasi, tungku, alat pengukur suhu, blender, ayakan 60 mesh, cetakan briket, timbangan, kompor, oven, cawan porselin, desikator, gelas ukur, alat uji kuat tekan (marshall compression machine) dan bomb calorimeter. Sementara bahan-bahan yang digunakan meliputi bahan baku briket (sampah buah, sampah plastik HDPE dan tempurung kelapa), tepung tapioka serta air yang digunakan untuk pembuatan perekat kanji.

\section{Uji karakteristik bahan baku}

Uji karakteristik yang dilakukan berupa uji kimia yang terdiri dari proximate analysis yaitu kadar air, kadar volatil, fixed carbon, dan kadar abu serta analisis nilai kalor masing-masing bahan baku. Uji karakteristik bahan baku dilakukan untuk mengetahui potensi dari masing-masing bahan baku pada parameter-parameter yang dihasilkan pada briket yang akan diuji.

\section{Pembuatan briket}

Proses pembuatan briket meliputi persiapan bahan baku yaitu sampah buah dan tempurung kelapa yang telah dijemur di bawah sinar matahari untuk menurunkan kadar air serta telah dicacah. Bahan baku lain yaitu sampah plastik HDPE dicuci bersih dan dipotong menjadi berukuran 1 $\mathrm{cm}$ untuk masing-masing sisinya. Tahapan selanjutnya yaitu karbonisasi (pengarangan) untuk sampah buah dan tempurung kelapa, sementara untuk sampah plastik HDPE tidak dikarbonisasi. Proses karbonisasi berlangsung dengan suhu diatas $500^{\circ} \mathrm{C}$ dan berlangsung selama kurang lebih 1-3 jam. Selanjutnya dilakukan penumbukan arang agar menjadi serbuk arang serta pengayakan. Pengayakan arang dilakukan untuk mendapatkan ukuran partikel serbuk arang yang seragam, yang dilakukan menggunakan ayakan ukuran 60 mesh.

Setelah didapatkan arang berukuran seragam, tahapan selanjutnya yang dilakukan adalah pembuatan perekat kanji. Perekat kanji dibuat dengan mencampurkan tepung kanji dengan air sambil dipanaskan di atas kompor dan diaduk hingga kental dan perekat merata sempurna. Tahapan terakhir yaitu pencetakan briket. Arang serta plastik HDPE dicampurkan dengan perekat dan diaduk hingga merata. Banyaknya arang dan plastik HDPE yang digunakan sesuai dengan komposisi masing-masing bahan dalam variasi briket. Rasio perbandingan arang dengan perekat yaitu 2:1. Adonan yang telah tercampur merata dimasukkan dalam cetakan berbentuk silinder berdiameter $4 \mathrm{~cm}$ dan tinggi $5 \mathrm{~cm}$. Selanjutnya dilakukan pencetakan dengan memberikan tekanan sebesar 1,5 ton $/ \mathrm{cm}^{2}$ menggunakan alat kempa. Briket yang telah dicetak, dikeluarkan dan dikeringkan selama 2-3 hari untuk menurunkan kadar air briket. Komposisi briket arang yang akan dibentuk tercantum dalam Tabel 1.

Tabel 1. Variasi Komposisi Bahan Baku Briket

\begin{tabular}{ccc}
\hline \multicolumn{3}{c}{ Variasi Komposisi Briket (\%) } \\
\hline SB & SP & TK \\
\hline 100 & - & - \\
- & - & 100 \\
50 & - & 50 \\
60 & 20 & 20 \\
40 & 20 & 40 \\
20 & 20 & 60 \\
\hline
\end{tabular}

\begin{tabular}{ll}
\hline Keterangan: \\
SB & : Sampah buah \\
SP & : Sampah plastik HDPE \\
TK & : Tempurung kelapa
\end{tabular}

Briket dalam berbagai variasi komposisi bahan baku yang telah dicetak dapat dilihat pada Gambar 1 . 


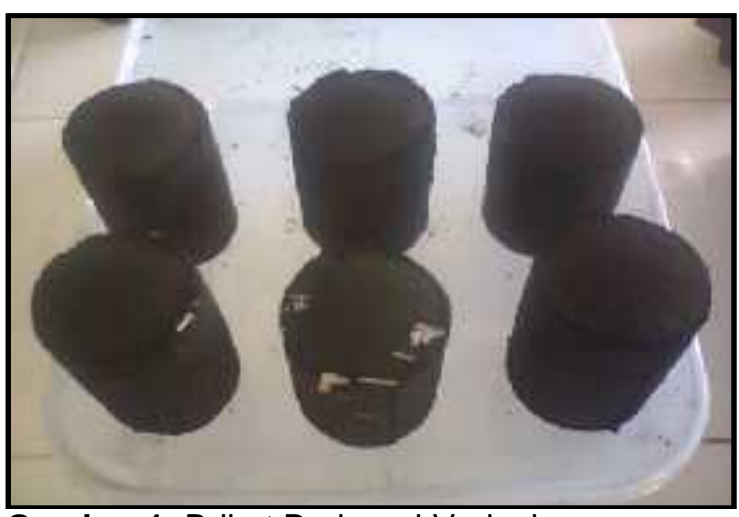

Gambar 1. Briket Berbagai Variasi

Pengujian mutu briket

Kerapatan dan volume briket dihitung dengan persamaan 1 dan 2 .

$$
\begin{gathered}
(\rho)=\frac{m}{V t o t} \\
\text { Vtot }=\eta r^{2} t
\end{gathered}
$$

Dimana:

$$
\begin{aligned}
\rho & =\text { Kerapatan briket }\left(\mathrm{g} / \mathrm{cm}^{3}\right) \\
\mathrm{m} & =\text { Massa briket }(\mathrm{g}) \\
\text { Vtot } & =\text { Volume total }\left(\mathrm{cm}^{3}\right) \\
\mathrm{r} & =\text { Jari-jari }(\mathrm{cm}) \\
\mathrm{t} & =\text { Tinggi briket }
\end{aligned}
$$

Kuat tekan briket (Kt) dihitung dengan persamaan 3 .

$\mathrm{Kt}\left(\mathrm{kg} / \mathrm{cm}^{2}\right)=\frac{\text { Gaya }}{\text { LuasPermukaan }}$

Alat uji kuat tekan marshall compression machine dapat dilihat dalam Gambar 2.

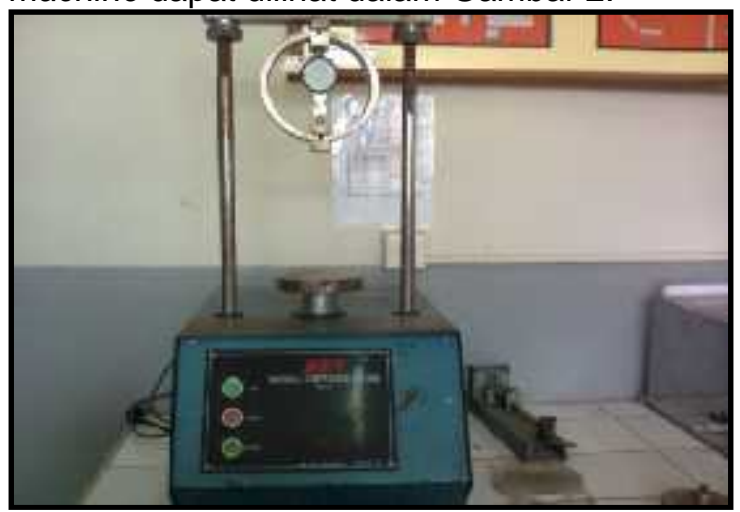

Gambar 2. Marshall Compression Machine

Kadar air briket dihitung dengan persamaan 4.

$\% \mathrm{KA}=\frac{B-C}{B-A} \times 100 \%$

Dimana:
$\mathrm{KA}=$ Kadar air (\%)
$\mathrm{A}=$ Cawan kosong
$\mathrm{B}$ = Cawan + sampel
$\mathrm{C}=$ Cawan + sampel (suhu $105^{\circ} \mathrm{C}$ )
Kadar volatil briket dihitung dengan persamaan 5 .

$\% \mathrm{KV}=\frac{B-C}{B-A} \times 100 \%$

Dimana:

$\mathrm{KV}=$ Kadar volatil (\%)

$\mathrm{A} \quad=$ Cawan kosong

B = Cawan + sampel

C = Cawan + sampel (suhu $600^{\circ} \mathrm{C}$ )

Kadar abu briket dihitung dengan persamaan 6 .

$\% \mathrm{KAb}=\frac{B-C}{B-A} \times 100 \%$

Dimana:

$\mathrm{KAb}=\mathrm{Kadar}$ abu (\%)

$\mathrm{A}=$ Cawan kosong

B = Cawan + sampel

C = Cawan + sampel (suhu $900^{\circ} \mathrm{C}$ )

Fixed carbon briket dihitung dengan persamaan (7).

$\% F C=100 \%-(K A+K V+K A b)$

Dimana:

$\mathrm{FC}=$ Fixed carbon (\%)

$\mathrm{KA}=$ Kadar Air (\%)

$\mathrm{KV}=$ Kadar volatil (\%)

$\mathrm{KAb}=$ Kadar abu (\%)

Pengujian nilai kalor briket dilakukan dengan menggunakan alat Bomb Calorimeter yang dapat dilihat dalam Gambar 3.

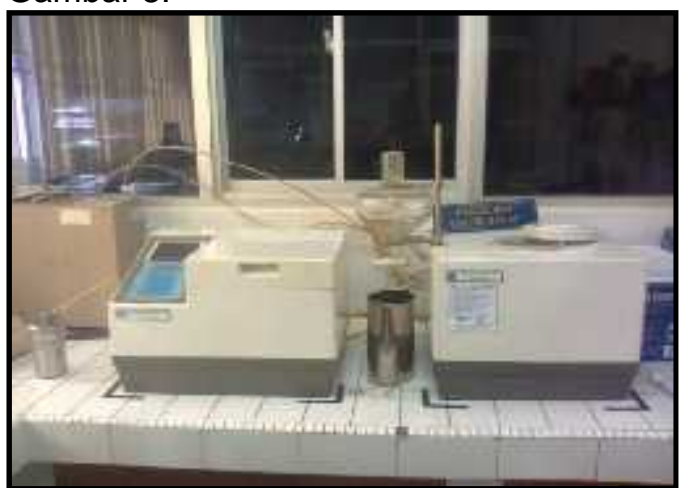

Gambar 3. Bomb Calorimeter

\section{HASIL DAN PEMBAHASAN Analisis bahan baku briket}

Analisis bahan baku dilakukan terhadap sampah buah, sampah plastik HDPE dan tempurung kelapa. Hasil proximate analysis bahan baku briket disajikan dalam Gambar 4. Kadar air tertinggi dihasilkan oleh sampah buah sebesar $71,80 \%$, dikarenakan sampah buah termasuk dalam golongan sampah organik basah yang diketahui mengandung kadar air yang tinggi. Kadar volatil tertinggi dihasilkan oleh sampah plastik HDPE sebesar 98,60\%, dikarenakan sampah plastik HDPE termasuk dalam golongan sampah yang mudah terbakar. Begitu juga halnya dengan tempurung kelapa merupakan golongan sampah yang mudah 
terbakar, menghasilkan kadar volatil sebesar $80,86 \%$.

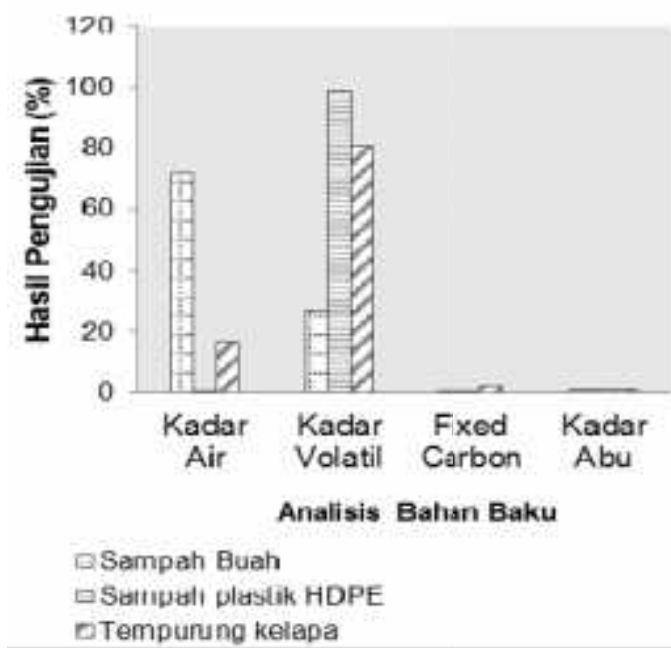

Gambar 4. Proximate Analysis Bahan Baku Briket

Fixed carbon tertinggi dihasilkan oleh tempurung kelapa sebesar $2,11 \%$, disebabkan tempurung kelapa memiliki kandungan karbon yang tinggi. Penelitian Budi (2011) menyebutkan bahwa kandungan karbon dalam tempurung kelapa sebesar 74,3\%. Kadar abu tertinggi dihasilkan oleh sampah buah sebesar $0,79 \%$. Kadar abu yang tinggi disebabkan kadar volatil sampah buah rendah, dimana pada saat pembakaran dengan suhu $600^{\circ} \mathrm{C}$ zat organik yang hilang tidak terlalu besar sehingga menghasilkan residu (abu) yang tinggi.

Nilai kalor tertinggi dihasilkan sampah plastik HDPE, sebesar $10.956 \mathrm{kal} / \mathrm{g}$. Hal ini disebabkan plastik merupakan material yang terdiri dari rantai karbon yang panjang serta elemen-elemen lain. Kandungan karbon inilah yang menyebabkan plastik mudah terbakar dan memiliki nilai kalor yang tinggi. Selain itu, jenis plastik HDPE juga diketahui memiliki nilai kalor yang lebih tinggi dibandingkan dengan plastik jenis polyethylene lainnya. Kerapatan (density) plastik HDPE juga lebih baik dibanding plastik jenis lain. Nilai kalor terendah dihasilkan oleh sampah buah yaitu sebesar $1.158 \mathrm{kal} / \mathrm{g}$. Hal ini disebabkan sampah buah memiliki kadar air yang tinggi. Kadar air tinggi menyebabkan penurunan nilai kalor yang dihasilkan (Listiyanawati, 2008). Hasil pengujian nilai kalor bahan baku briket dapat dilihat pada Gambar 5 .

\section{Kerapatan}

Tinggi rendahnya nilai kerapatan sangat dipengaruhi oleh keseragaman atau kehomogenan ukuran partikel arang penyusun briket. Kerapatan briket yang diuji dalam penelitian ini berkisar antara 0,60 $\mathrm{g} / \mathrm{cm}^{3}-0,89 \mathrm{~g} / \mathrm{cm}^{3}$. Nilai tertinggi dihasilkan oleh briket 100TK sebesar $0,89 \mathrm{~g} / \mathrm{cm}^{3}$, sedangkan kerapatan terendah dihasilkan dari briket $100 \mathrm{SB}$ sebesar $0,60 \mathrm{~g} / \mathrm{cm}^{3}$. Hasil pengujian kerapatan tiap variasi briket disajikan dalam Gambar 6.

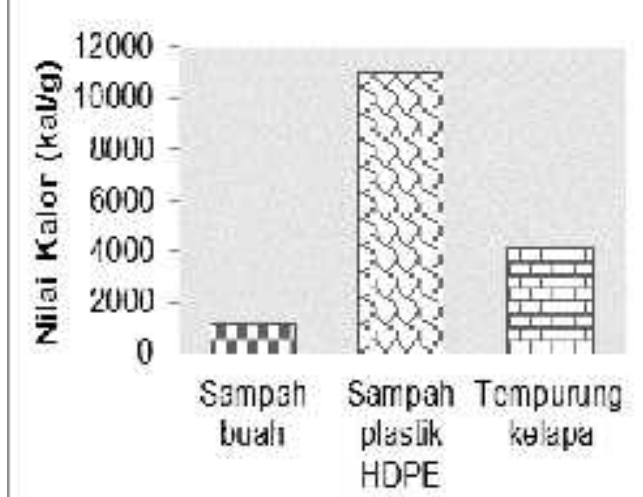

Bahan Baku

\section{E Sarnualı bust। \\ E Sampalı plaslik HDFE \\ ETenupurury kelaps}

Gambar 5. Nilai Kalor Bahan Baku Briket Karakteristik Fisik Briket

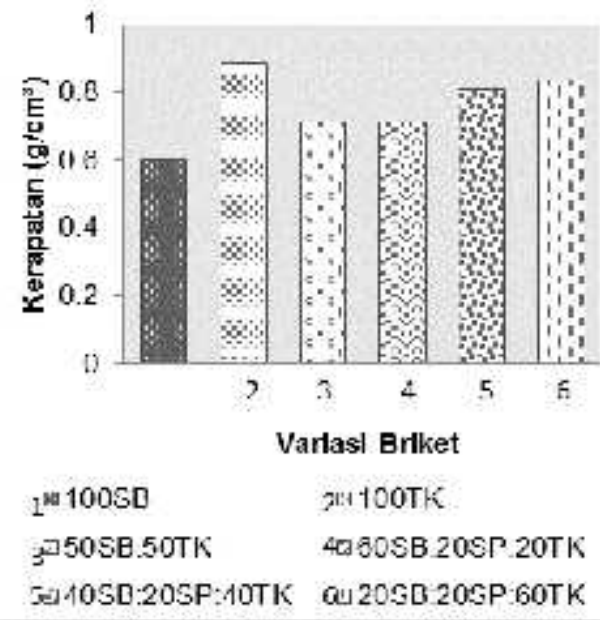

Gambar 6. Kerapatan Variasi Briket

Tingginya kerapatan yang dihasilkan briket 100TK dipengaruhi oleh berat jenis dari tempurung kelapa yang juga tinggi, yaitu $0,95 \mathrm{~g} / \mathrm{cm}^{3}$. Kayu yang mempunyai berat jenis tinggi akan menghasilkan arang dengan kerapatan yang tinggi, sedangkan kayu yang mempunyai berat jenis rendah akan menghasilkan arang dengan kerapatan yang rendah pula.

Pada Gambar 6 dapat dilihat pengaruh komposisi arang tempurung kelapa terhadap peningkatan nilai kerapatan briket. Semakin banyak komposisi arang tempurung kelapa dalam setiap variasi briket menyebabkan peningkatan nilai kerapatan briket, seperti yang terlihat dari grafik 4 sampai 6 . Selain itu, pengayakan yang dilakukan menggunakan ayakan 60 mesh menghasilkan ukuran partikel arang yang 
seragam sehingga menyebabkan peningkatan nilai kerapatan briket. Ukuran partikel yang tidak seragam mengakibatkan penempelan dan pengikatan partikel kurang sempurna.

\section{Kuat Tekan}

Nilai kuat tekan sangat dipengaruhi oleh jenis bahan baku, ukuran partikel, densitas partikel, jenis perekat, tekanan pemampatan dan kerapatan produk. Semakin tinggi nilai kerapatan suatu produk maka semakin tinggi pula nilai kuat tekan yang dihasilkan (Sani, 2009). Uji kuat tekan dilakukan menggunakan alat marshall compression machine. Hasil pengujian kuat tekan setiap variasi briket dapat dilihat pada Gambar 7.

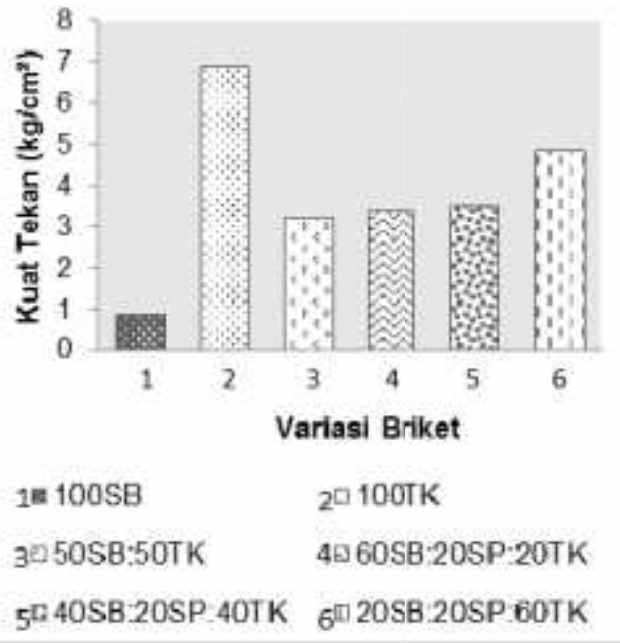

Gambar 7. Kuat Tekan Variasi Briket

Kuat tekan yang dihasilkan berkisar antara $0,88 \mathrm{~kg} / \mathrm{cm}^{2}-6,87 \mathrm{~kg} / \mathrm{cm}^{2}$. Nilai kuat tekan tertinggi dihasilkan oleh briket 100TK sebesar $6,87 \mathrm{~kg} / \mathrm{cm}^{2}$, sedangkan nilai terendah dihasilkan oleh briket 100SB sebesar 0,88 $\mathrm{kg} / \mathrm{cm}^{2}$. Tingginya kuat tekan briket 100TK dikarenakan komposisi utama variasi briket ini adalah tempurung kelapa, dimana Hendra dan Winarni (2003) dalam penelitiannya menyatakan bahwa tingginya angka kerapatan dan kuat tekan pada briket arang dari bahan baku kayu yang memiliki berat jenis tinggi disebabkan serat kayu yang lebih rapat dan komponen selulosa pada dinding sel lebih banyak.

Dari Gambar 7, terlihat adanya kecenderungan peningkatan nilai kuat tekan dengan semakin banyaknya komposisi arang tempurung kelapa dalam variasi briket, yang ditunjukkan oleh grafik 4 sampai 6. Hal ini membuktikan bahwa nilai kerapatan mempengaruhi nilai kuat tekan, dimana jika nilai kerapatan tinggi, maka nilai kuat tekan yang dihasilkan pun akan tinggi

Selain itu, tekanan yang diberikan saat proses pencetakan briket yaitu sebesar 1,5 ton/ $\mathrm{cm}^{2}$, juga merupakan salah satu faktor yang menyebabkan tingginya nilai kerapatan yang dihasilkan pada penelitian ini. Tekanan yang besar akan menyebabkan masuknya perekat ke dalam ruang kosong di antara serbuk arang sehingga akan menghasilkan kerapatan yang tinggi.

\section{Karakteristik Kimia Kadar Air}

Kadar air pada briket mempengaruhi nilai kalor dan daya pembakaran. Semakin rendah kadar air maka semakin tinggi nilai kalor dan daya pembakarannya. Kadar air yang tinggi dapat menyulitkan proses penyalaan briket (Sani, 2009). Kadar air yang dihasilkan briket dalam penelitian ini berkisar antara 5,73\%-9,06\%. Kadar air tertinggi didapat pada briket 100SB sebesar 9,06\%, sedangkan kadar air terendah didapat pada briket $100 \mathrm{TK}$ sebesar 5,73\%. Tingginya kadar air briket 100SB disebabkan karena sampah buah memiliki kadar air yang tinggi. Hal ini sesuai dengan hasil pengujian bahan baku yaitu sebesar 71,80\%. Hasil pengujian kadar air untuk semua variasi briket dapat dilihat pada Gambar 8.

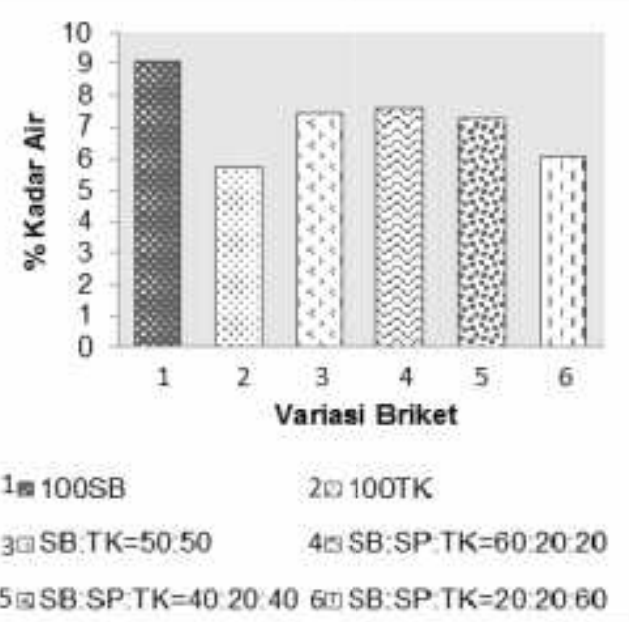

Gambar 8. Kadar Air Variasi Briket

Pada Gambar 8 terlihat adanya kecenderungan penurunan kadar air dengan semakin berkurangnya persentase komposisi sampah buah pada variasi briket. Variasi briket dengan penambahan komposisi sampah plastik HDPE menghasilkan kadar air berkisar antara $6,10 \%-7,57 \%$, dimana kadar air tertinggi dihasilkan oleh briket 60SB:20SP:20TK sebesar $7,57 \%$.

Selain itu, faktor yang juga mempengaruhi persentase kadar air pada penelitian ini adalah proses karbonisasi. Proses karbonisasi dapat menyebabkan nilai kadar air berkurang. Kadar air tempurung kelapa sebelum dikarbonisasi yaitu sebesar $16,28 \%$ dan kadar air 
tempurung kelapa setelah dikarbonisasi yaitu sebesar 5,73\%. Begitu pula untuk sampah buah, kadar air sebelum dikarbonisasi yang didapat sebesar 71,80\% dan kadar air setelah dikarbonisasi yang didapat sebesar 9,06\%.

Setelah proses karbonisasi, terjadi penurunan kadar air kurang lebih sebesar $87 \%$ pada sampah buah dan $65 \%$ pada tempurung kelapa. Hal ini disebabkan karena salah satu tahapan proses karbonisasi adalah tahap penguapan air yang terjadi pada suhu $100^{\circ} \mathrm{C}-150^{\circ} \mathrm{C}$.

\section{Kadar Volatil}

Makin besar kadar volatil maka briket akan lebih cepat terbakar, namun juga berakibat pada singkatnya waktu nyala briket tersebut. Tinggi rendahnya kadar volatil sangat bergantung pada jenis bahan baku yang digunakan. Hasil pengujian kadar volatil semua variasi briket dapat dilihat pada Gambar 9.

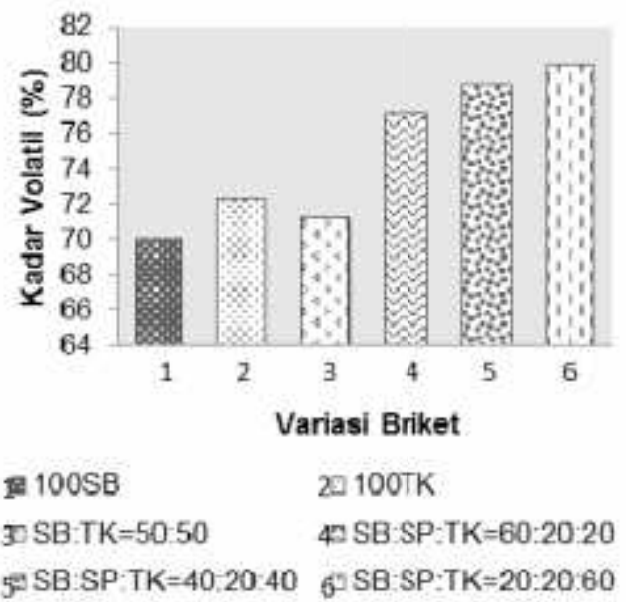

Gambar 9. Kadar Volatil Variasi Briket

Kadar volatil dalam penelitian ini berkisar antara 70,02-79,92\%. Kadar volatil tertinggi didapat pada briket 20SB:20SP:60TK sebesar 79,92\%, sedangkan kadar volatil terendah didapat pada briket 100SB sebesar 70,02\%. Tingginya kadar volatil briket 20SB:20SP:60TK disebabkan adanya penambahan komposisi sampah plastik HDPE dan tingginya komposisi tempurung kelapa dalam variasi briket. Hal ini dibuktikan dengan pengujian bahan baku, dimana sampah plastik HDPE menghasilkan kadar volatil tertinggi sebesar $98,60 \%$, diikuti dengan tempurung kelapa yang menghasilkan kadar volatil sebesar $82,68 \%$.

Briket dengan penambahan 20\% sampah plastik HDPE ditunjukkan dari grafik 4 sampai 6 , menghasilkan kadar volatil berkisar antara 77,11-79,92\%, sedangkan variasi briket yang tidak mengandung sampah plastik yang ditunjukkan dari grafik 1 sampai 3, menghasilkan kadar volatil berkisar antara 70,02\%-72,32\%. Himawanto (2005) menyatakan bahwa penambahan bahan anorganik akan meningkatkan kadar volatil, sehingga mempercepat terjadinya pembakaran.

\section{Fixed Carbon}

Semakin tinggi kadar fixed carbon pada briket, maka nilai kalor pembakaran briket semakin baik. Kadar fixed carbon yang didapat dari penelitian ini berkisar antara $12,39-18,41 \%$. Nilai fixed carbon tertinggi didapat pada briket 100TK sebesar $18,41 \%$, sedangkan nilai terendah pada briket 60SB:20SP:20TK sebesar 12,39\%. Hasil pengujian fixed carbon semua variasi briket dapat dilihat pada Gambar 10.

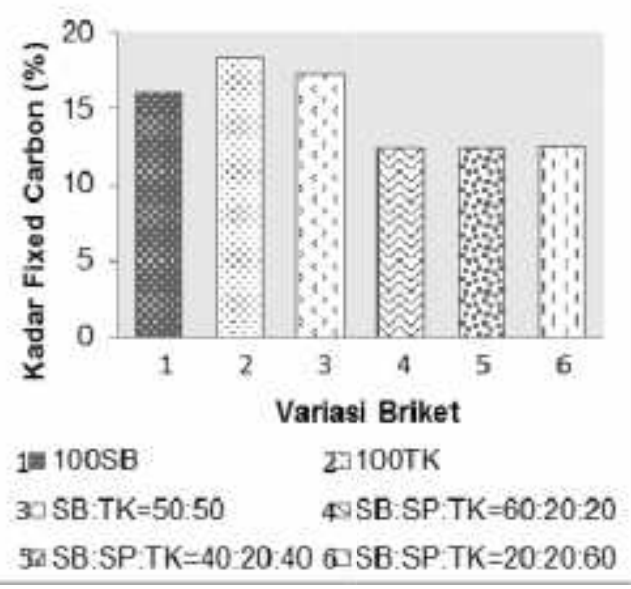

Gambar 10. Fixed Carbon Variasi Briket

Tingginya nilai fixed carbon pada briket 100TK ini disebabkan tingginya kandungan lignin dalam tempurung kelapa. Menurut penelitian Komarayati et al (2004), semakin tinggi lignin yang terkandung dalam bahan baku briket menyebabkan semakin besar nilai karbon terikatnya. Selain itu, dari pengujian bahan baku, didapat hasil yang menunjukkan bahwa tempurung kelapa menghasilkan kadar fixed carbon tertinggi dibandingkan dengan dua bahan baku lainnya, yaitu sebesar $2,11 \%$.

Kadar Abu

Kadar abu merupakan unsur pengotor, sehingga kadar abu yang tinggi akan berpengaruh pada tingkat korosi alatalat yang digunakan yang menyebabkan alat akan cepat rusak. Dari Gambar 11 terlihat kadar abu arang sampah buah lebih tinggi dibandingkan kadar abu arang tempurung kelapa, yaitu sebesar $4,86 \%$. Dari grafik 4 sampai grafik 6 pada gambar 
11 , terjadi kecenderungan penurunan kadar abu dengan semakin berkurangnya komposisi sampah buah dalam variasi briket. Hal ini disebabkan sampah buah merupakan bahan baku yang diperkirakan memiliki kandungan mineral-mineral yang tinggi seperti kalsium, kalium, silikat dan yang lainnya, sehingga menghasilkan abu sisa pembakaran lebih banyak.

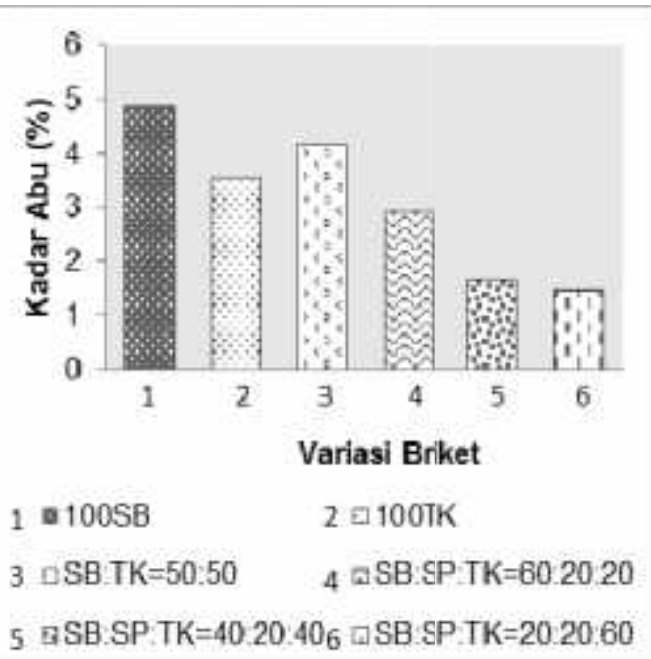

Gambar 11. Kadar Abu Variasi Briket

Tingginya kadar abu diduga karena

bahan baku mempunyai kadar garamgaram karbonat, kalium, kalsium, magnesium dan kadar silikat yang tinggi. Semakin tinggi kadar silikat akan menyebabkan semakin tinggi kadar abu yang dihasilkan, karena silikat tidak terbakar. Kadar abu yang diperoleh dalam penelitian ini berkisar antara 1,47-4,86\%. Kadar abu tertinggi dihasilkan oleh briket 100SB sebesar $4,86 \%$, sedangkan kadar abu terendah pada briket 20SB:20SP:60TK sebesar $1,47 \%$. Penurunan nilai kadar abu terlihat jelas pada briket dengan bahan baku yang mengandung sampah plastik HDPE. Hal ini disebabkan bahan baku sampah plastik HDPE menghasilkan kadar abu yang rendah yaitu $0,77 \%$.

Nilai Kalor

Semakin tinggi nilai kalor yang dihasilkan briket maka semakin baik kualitas briket, sehingga briket semakin berpotensi digunakan sebagai bahan bakar alternatif. Nilai kalor tertinggi dihasilkan oleh briket 20SB:20SP:60TK sebesar 7.213 $\mathrm{kal} / \mathrm{g}$. Nilai kalor terendah dihasilkan oleh briket 100SB sebesar $4.549 \mathrm{kal} / \mathrm{g}$. Tinggi rendahnya nilai kalor salah satunya dipengaruhi oleh jenis bahan baku yang digunakan. Hasil pengujian nilai kalor semua variasi briket disajikan pada Gambar 12.

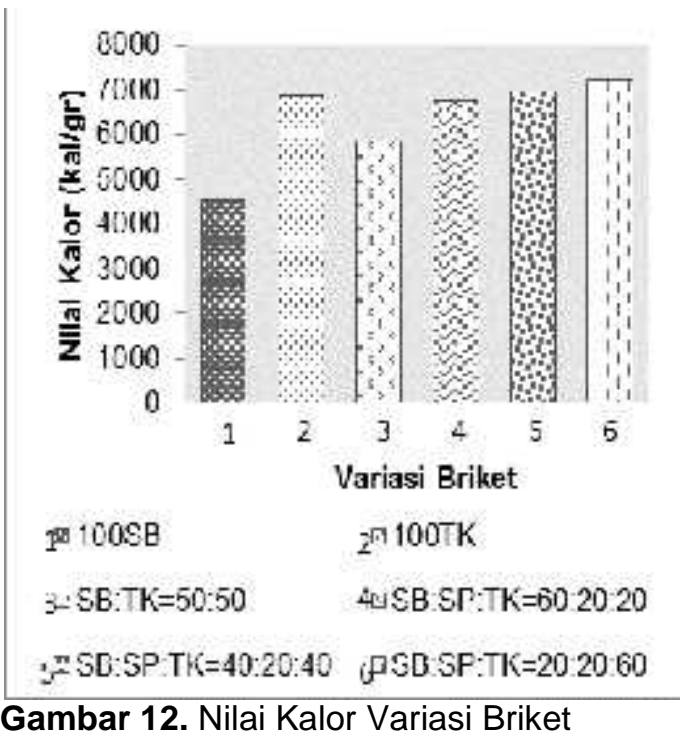

Gambar 12 menunjukkan variasi briket yang mengandung $20 \%$ sampah plastik HDPE, cenderung menghasilkan nilai kalor yang lebih baik dibandingkan dengan variasi briket yang tidak mengandung sampah plastik HDPE. Hal ini dikarenakan dari pengujian bahan baku sampah plastik HDPE didapatkan nilai kalor yang tinggi. Nilai kalor yang dihasilkan briket dalam penelitian ini berkisar antara $4.549 \mathrm{kal} / \mathrm{g}-7.213 \mathrm{kal} / \mathrm{g}$. Nilai kalor tertinggi dihasilkan oleh briket 20SB:20SP:60TK dengan nilai sebesar $7.213 \mathrm{kal} / \mathrm{g}$. Nilai kalor terendah dihasilkan oleh briket 100SB dengan nilai sebesar $4.549 \mathrm{kal} / \mathrm{g}$.

Selain adanya penambahan sampah plastik HDPE, peningkatan nilai kalor yang ditunjukkan dari grafik 4 sampah 6 pada gambar 12, juga dipengaruhi oleh makin meningkatnya komposisi tempurung kelapa dalam variasi briket. $\mathrm{Hal}$ ini dikarenakan tempurung kelapa memiliki kandungan karbon yang tinggi sehingga menghasilkan nilai kalor yang juga tinggi.

Peningkatan nilai kalor juga dipengaruhi oleh proses karbonisasi. Dari pengujian bahan baku diketahui terjadi peningkatan yang signifikan dari sampah buah dan tempurung kelapa sebelum karbonisasi dan setelah karbonisasi. Proses karbonisasi bertujuan untuk mengubah bahan baku menjadi arang sehingga dapat meningkatkan kadar karbon dan menaikkan nilai kalor.

\section{Analisis Biaya Briket}

Biaya pembuatan briket dihitung dari harga bahan baku yang digunakan dan biaya proses pembuatan briket, tanpa memperhitungkan upah pekerja dan lama pembuatan. Hasil perhitungan analisis biaya dapat dilihat pada Tabel 1 .

Tabel 1 Analisis Biaya Pembuatan Briket 


\begin{tabular}{lll}
\hline Variasi Briket & $\begin{array}{l}\text { Harga } \\
\text { per kg } \\
\text { Briket } \\
\text { (Rp/kg) }\end{array}$ & $\begin{array}{l}\text { Harga } \\
\text { per kal } \\
\text { (Rp/kkal) }\end{array}$ \\
\hline 100SB & 3,93 & 0,86 \\
100TK & 4,05 & 0,59 \\
50SB:50TK & 3,96 & 0,67 \\
60SB:20SP:20TK & 3,93 & 0,58 \\
40SB:20SP:40TK & 4,00 & 0,58 \\
20SB:20SP:60TK & 4,05 & 0,56 \\
\hline \multicolumn{2}{c}{ Pada Tabel 1, terlihat biaya }
\end{tabular}

pembuatan briket terbesar per kkal adalah briket 100SB dan biaya pembuatan briket terkecil per kkal adalah briket 20SB:20SP:60TK. Data harga bahan bakar lain dapat dilihat pada Tabel 2 .

Tabel 2. Harga Bahan Bakar

\begin{tabular}{clc}
\hline No. & \multicolumn{1}{c}{ Bahan Bakar } & $\begin{array}{c}\text { Harga } \\
\text { (Rp/kkal) }\end{array}$ \\
\hline 1. & Minyak tanah & 0,73 \\
2. & Elpiji & 0,25 \\
3. & Briket batubara & 0,56 \\
\hline
\end{tabular}

Sumber: Radita (2009)

Variasi briket dengan penambahan komposisi sampah plastik HDPE menghasilkan biaya sebesar Rp. 0,56/kkalRp 0,58/kkal. Jika dibandingkan dengan harga beberapa bahan bakar seperti yang tercantum pada Tabel 2, diketahui harga briket ini lebih murah dibandingkan dengan harga minyak tanah yang berkisar Rp. 0,73/kkal dan hampir setara dengan harga batubara yang berkisar Rp. 0,56/kkal. Namun harga briket pada penelitian ini melebihi harga LPG yang berkisar Rp. $0,25 /$ kkal. Dibandingkan dengan harga LPG per kkal-nya, produk briket ini dinilai kurang ekonomis. Namun jika dibandingkan dengan harga minyak tanah dan batubara per kkal-nya, produk briket ini dinilai lebih ekonomis sehingga dapat dijadikan sebagai alternatif pengganti minyak tanah dan batubara di rumah tangga.

Perbandingan dengan Baku Mutu dan Beberapa Penelitian Terkait

Hasil penelitian briket bioarang ini dibandingkan dengan Permen ESDM No. 047 Tahun 2006 tentang briket biobarubara, dikarenakan belum adanya standar untuk briket bioarang. Semua variasi briket pada penelitian ini telah memenuhi standar yang dipersyaratkan dalam Permen ESDM No. 047 Tahun 2006 untuk parameter kadar air dan nilai kalor. Kadar air maksimum yang diperbolehkan untuk briket adalah 15\%. Kadar air yang didapat dari variasi briket dalam penelitian ini berkisar antara 5,73-9,06\%. Nilai kalor yang dipersyaratkan untuk biobriket minimal $4.400 \mathrm{kal} / \mathrm{g}$. Dalam penelitian ini, nilai kalor yang diperoleh untuk semua briket berkisar antara $4.549-7.213 \mathrm{kal} / \mathrm{g}$.

Dalam Permen ESDM No. 047

Tahun 2006, ketentuan untuk kadar volatil tidak ditetapkan dengan angka yang spesifik, namun standar disesuaikan dengan bahan baku. Kadar volatil yang didapat pada penelitian ini cukup tinggi, selain dikarenakan adanya penambahan sampah plastik HDPE, juga disebabkan oleh tempurung kelapa, yang diketahui menghasilkan kadar volatil tinggi.

Untuk paremeter kuat tekan, hasil yang diperoleh dalam penelitian ini belum memenuhi Permen ESDM No. 047 Tahun 2006. Hal ini dikarenakan pada Permen ESDM No. 047 Tahun 2006, standar ketetapan mengacu pada briket biobatubara. Briket bio-batubara merupakan campuran antara biomassa dan batubara, dimana batubara diketahui memiliki struktur yang lebih padat serta kuat tekan yang lebih baik dibandingkan biomassa. Persyaratan kuat tekan untuk briket biobatubara minimal $65 \mathrm{~kg} / \mathrm{cm}^{2}$, sedangkan kuat tekan briket dalam penelitian ini berkisar antara 0,88-6,87 kg/cm ${ }^{2}$. Namun jika dibandingkan dengan penelitian tentang briket bioarang di beberapa negara, kuat tekan yang dihasilkan juga lebih kecil yaitu berkisar $12-60 \mathrm{~kg} / \mathrm{cm}^{2}$, seperti terlihat pada Tabel 3.

Parameter lain yang diuji pada penelitian ini seperti fixed carbon, kadar abu dan kerapatan tidak terdapat ketentuannya dalam Permen ESDM No. 047 Tahun 2006. Oleh karena itu perbandingan dilakukan dengan penelitian terkait yang menggunakan bahan baku yang hampir sama. Perbandingan dilakukan dengan penelitian Anggraini (2005) yang menggunakan bahan baku briket dari komposit sampah plastik HDPE dan sampah kebun, serta penelitian Hendra (2007) yang menggunakan campuran limbah kayu gergajian dan sebetan kayu sebagai bahan baku. Dari hasil perbandingan didapatkan mutu briket pada penelitian ini sudah lebih baik. Kerapatan yang dihasilkan briket pada penelitian Hendra (2007) berkisar $0,46-0,71 \mathrm{~g} / \mathrm{cm}^{2}$, sedangkan dalam penelitian ini lebih tinggi yaitu $0,60-0,89 \mathrm{~g} / \mathrm{cm}^{3}$. Untuk parameter fixed carbon dalam penelitian ini juga lebih tinggi dibandingkan dengan penelitian Anggraini (2005). Fixed carbon penelitian ini berkisar 12,39-18,41\%, sedangkan penelitian Anggraini (2005) berkisar 2,89$3,50 \%$. Nilai kadar abu briket dalam penelitian ini juga sudah lebih rendah dibandingkan dengan peneltian Anggraini (2005). Nilai kadar abu briket penelitian ini berkisar 1,47-4,86\%, sedangkan briket 
pada penelitian Anggraini (2005).berkisar 37,28-38,96\%.

Pemilihan Briket Optimum

Berdasarkan hasil penelitian, diketahui briket optimum pada penelitian ini adalah briket 20SB:20SP:60TK. Hal ini disebabkan briket 20SB:20SP:60TK memiliki keunggulan terbanyak, diantaranya nilai kerapatan tinggi, kuat tekan tinggi, kadar air rendah, fixed carbon tinggi, kadar abu rendah, nilai kalor tertinggi serta harga briket termurah jika dibandingkan briket variasi lain. Selanjutnya diikuti dengan briket 100TK, briket 40SB:20SP:40TK dan briket 60SB:20SP:20TK dengan nilai yang tidak berbeda signifikan. Briket yang memiliki komposisi sampah plastik HDPE, memiliki nilai yang tidak jauh berbeda satu sama lainnya. Oleh karena itu, dua variasi briket lain yang mengandung plastik HDPE juga dapat dimanfaatkan sebagai bahan bakar alternatif karena nilai yang dihasilkan tidak jauh berbeda dengan briket optimum.

\section{Tabel 3. Standar Kualitas Bioarang}

\begin{tabular}{lcccc}
\hline \multicolumn{1}{c}{ Sifat Briket Arang } & \multicolumn{4}{c}{ Kualitas Briket Arang } \\
\cline { 2 - 5 } & Jepang & Inggris & Amerika & Indonesia \\
\hline Kadar air (\%) & $6-8$ & $3-4$ & 6 & 7.75 \\
Kadar abu (\%) & $3-6$ & & & 5.51 \\
Kadar zat menguap (\%) & $15-30$ & & & 16.14 \\
Kadar karbon terikat (\%) & $60-80$ & & 78.35 \\
Kerapatan $\left(\mathrm{g} / \mathrm{cm}^{3}\right.$ ) & $1-2$ & 0.84 & 18 & 19 \\
Kuat tekan $\left(\mathrm{kg} / \mathrm{cm}^{2}\right.$ ) & 60 & 12.7 & 16 & 58 \\
Nilai kalor (kal/g) & $6000-7000$ & 6500 & 75 & \\
\hline
\end{tabular}

Sumber: Hendra dan Sumber: * Anggraini, $2005{ }^{* \star}$ Hendra, 2007

\section{KESIMPULAN}

Analisis terhadap bahan baku briket didapatkan sampah buah memiliki kadar air dan kadar abu tertinggi, sampah plastik HDPE memiliki kadar volatil dan nilai kalor tertinggi serta tempurung kelapa memiliki fixed carbon tertinggi.

Hasil uji karakteristik fisik dan kimia variasi briket menghasilkan kerapatan 0,60 $0,89 \mathrm{~g} / \mathrm{cm}^{3}$, kuat tekan $0,88-6,87 \mathrm{~kg} / \mathrm{cm}^{2}$, kadar air 5,73-9,06\%, kadar volatil 70,02$79,92 \%$, fixed carbon $12,39-18,41 \%$, kadar abu $1,47-4,86 \%$ serta nilai kalor 4.549$7.213 \mathrm{kal} / \mathrm{g}$. Briket ini telah memenuhi standar Permen ESDM No. 047 Tahun 2006, kecuali untuk parameter kuat tekan.

Harga briket pada penelitian lebih ekonomis jika dibandingkan dengan harga minyak tanah dan hampir setara dengan harga briket batubara, namun masih lebih tinggi jika dibandingkan dengan harga LPG;

Briket yang dihasilkan pada penelitian ini dapat digunakan sebagai bahan bakar alternatif karena telah memenuhi standar briket dari segi karakteristik fisik dan kimia briket, serta lebih ekonomis ditinjau dari aspek biaya. Briket optimum adalah briket dengan komposisi sampah buah $20 \%$, sampah plastik HDPE $20 \%$ dan tempurung kelapa $60 \%$.

\section{DAFTAR PUSTAKA}

Abdullah, K. 2002. Biomass Energy Potential and Utilization in Indonesia. Lembaga Penelitian dan Pengembangan Masyarakat. Fakultas Teknologi Pertanian. Institut Pertanian Bogor, Bogor.
Angraini, S. Ratna. 2005. Eko-briket dari Komposit Sampah Plastik High Density Polyethylene (HDPE) dan Arang Sampah Kebun. Institut Teknologi Surabaya. Surabaya.

Budi, E. 2011. Tinjauan Proses Pembentukan dan Penggunaan Arang Tempurung Kelapa Sebagai Bahan Bakar. Jurusan Fisika, Fakultas MIPA. Universitas Negeri Jakarta. Jakarta

Hendra, D. 2007. Pembuatan Briket Arang dari Campuran Kayu, Bambu, Sabut Kelapa dan Tempurung Kelapa sebagai Sumber Energi Alternatif. Institut Pertanian Bogor. Bogor

Hendra, D dan Winarni, I. 2003. Sifat fisis dan kimia briket arang campuran Limbah Kayu Gergajian dan Sebetan Kayu. Jurnal Penelitian Hasil Hutan Vol. 21 No.31: 211226.

Hermawan, Y. 2006. Pemanfaatan Limbah Sekam Padi Sebagai Bahan Bakar Dalam Bentuk Briket. Jurusan Teknik Mesin Fakultas Teknik Universitas Jember. Jember.

Himawanto, D. A. 2005. Pengaruh Temperatur Karbonasi terhadap Karakteristik Pembakaran Briket. Jurnal Media Mesin, Volume 6 No. 2.

Komarayati, S., Setiawan, D., Mahpudin. 2004. Beberapa Sifat dan Pemanfaatan Arang dari Serasah dan Kulit Kayu Pinus. Jurnal 
Penelitian Hasil Hutan Vol. 22 No.1.

Listiyanawati, D. 2008. Eko Briket dari Sampah Plastik dan Lignoselulosa sebagai Alternatif Bahan Bakar. Tesis Jurusan Teknik Lingkungan FTSP-ITS, Surabaya.

PERMEN ESDM No. 047 Tahun 2006.

Pedoman Pembuatan dan Pemanfaatan Briket Batubara dan Bahan Bakar Padat Berbasis Batubara.

Prasetiyo, 2008. Eco-Briquette Dari Komposit Sampah Plastik High Density Polyethylene dan Sampah Lignoselulosa .Tugas Akhir, Jurusan Teknik Lingkungan, FTSP, Institut Teknologi Sepuluh November. Surabaya. 